\title{
Fluvial stacking due to plate collision and uplift during the Early Pleistocene in Cyprus
}

Research Article

\author{
1 Department of Geology, \\ Heinrich Heine University, Düsseldorf, Germany \\ 2 Department für Geo- und Umweltwissenschaften, Sektion Geophysik, \\ Theresienstr. 41, 80333 München, Germany \\ 3 Department of Earth Sciences, University College London, \\ Gower Street, London WC1E 6BT, England \\ 4 Institut für Geophysik, ETH-Zentrum NO D65, \\ Sonneggstr. 5, 8092 Zürich, Switzerland \\ 5 Geographisches Institut der RWTH, \\ Wüllnerstr. 5-7, 52056 Aachen, Germany \\ 6 Cyprus Geological Survey, \\ 1415 Lefkosia, Cyprus
}

Wolfgang Schirmer ${ }^{1 * \dagger}$, Josef Weber $^{2}$, Valerian Bachtadse ${ }^{3}$, Marcelle BouDagher-Fadel ${ }^{3}$, Friedrich Heller ${ }^{4}$, Frank Lehmkuhl ${ }^{5}$, Ioannis Panayides ${ }^{6}$, Ursula Schirmer ${ }^{1}$

Received 20 April 2010; accepted 1 July 2010

\begin{abstract}
Southern Cyprus is situated within a mosaic terrane that has been fragmented between the northward drifting African and Arabian plates and the Eurasian plate. Enormous uplift of the earth mantle in the Tróodos Mountains is explained by two models. The subduction model explains subduction along the Cyprean arc to be the driving force for uplift whereas after the restraining bend model westward squeezing of Cyprus along strike-slip faulting is responsible for the enormous uplift at restraining bends. Since its emergence as an island in early Miocene times, landscape formation on Cyprus has been strongly controlled by this uplift. Until the Plio-Pleistocene, a strait belt separated the southern unroofed ophiolitic core region-the Tróodos Mountainsfrom the folded Kyrenia range to the north. This former sea basin, nowadays the Mesaoría Basin, is linked with the Tróodos Mountains by a dissected glacis with a thick cover of river deposits. The highest and oldest river deposits (Apalós Formation) were studied in the Vlokkariá hill southwest of Lefkosía. The $45.5 \mathrm{~m}$ thick Apalós Formation of Early Pleistocene age exhibits 24 sedimentary units (Fluviatile Series). Their magnetostratigraphical characters align with the Matuyama chron including the Olduvai and Jaramillo subchrons thus comprising about $1.15 \mathrm{Ma}$ within the Early Pleistocene. This fluvial stack indicates a very flat and deeply lying river environment flowing from a slowly uplifting Tróodos hinterland. It happened during the end of Early Pleistocene when the enhanced Tróodos uplift started the dissection of the stacked river plain.
\end{abstract}

Keywords: Apalós Formation • Nicosia Formation • fluviatile stack • palaeomagnetism • Matuyama chron (C) Versita Warsaw 


\section{Introduction}

Cyprus is located in the interaction zone between the African, Arabian and Eurasian plates. It is part of the numerous terranes fragmented during the northward drift of the African and Arabian plates. This northward drift against the Eurasian plate caused a westward squeezing of Cyprus as well as of the Anatolian microplate. This westerly-directed escape tectonic regime of Cyprus produced - following the most recently postulated hypothesis - strike-slip faulting combined with enormous uplift along restraining bends of these tangential movements [1, 2]. Another model, the subduction model, explains subduction along the Cyprean arc - a zone situated $20 \mathrm{~km}$ beyond the southern coast of Cyprus - to be the driving force for uplift [3-5].

The Neogene and Quaternary development of the central part of Cyprus is determined by the uplift of the Tróodos ophiolite complex (Figure 1). All stratigraphical units of its sedimentary cover reflect the movements of this ophiolite complex. The uplift resulting in an island in the early Miocene [6] is supported by serpentinite diapirism of earth mantle material [7]. Since that time the development of the southern part of Cyprus and its adjacent marine border has been controlled by a submarine and later terrestrial radial sedimentary transport away from the uplifting ophiolite area.

The following text deals with the terrestrial sediment transport and uplift rate during the Early Pleistocene at the northern border of the Tróodos ophiolite complex.

\section{Geological setting}

Cyprus roughly consists of two mountain ranges, the ophiolitic Tróodos Mountains in the south and the folded Kyrenia Range in the north, with the 15-20 km wide Mesaoría intra-mountain basin in between (Figure 1). The Tróodos Mountains form the core of the Tróodos terrane, which borders the Kyrenia terrane along the Ovgos fault zone in the northern part of the Mesaoría. This fault zone shows left-lateral strike-slip and southward thrust fault character [1].

The ophiolitic Tróodos terrane represents an obduction slice $[2,3]$ of uppermost mantle and oceanic crust of Upper Cretaceous age onto continental crust. The Tróodos Mountains represent the ophiolitic core of the Tróodos terrane unroofed from its circum Tróodos sedimentary succession. This succession (Campanian to Recent) covers the Tróodos terrane outside the unroofed ophiolitic core. The rocks exposed at the surface in the Tróodos Mountains range from altered mantle rocks (harzburgite, dunite, serpentinite) to plutonic rocks (dunite, wehrlite, pyroxenite, gabbro, plagiogranite) to sheeted dykes (basalt) and volcanic rocks (andesite, basalt). The range's northern slope draining towards Lefkosía (Nicosía) exhibits mainly the sheeted dykes and volcanic sequence. These rocks dominate the fluvial deposits discussed in this paper.

The Kyrenia Range consists of an allochthonous ridge of Carboniferous through Miocene age consisting mainly of carbonate rocks. It is resting predominantly on folded Miocene flysch deposits. These Kyrenia rocks do not affect the fluvial drainage of the northern Tróodos slope.

The Mesaoría Basin was formed in the late Miocene [2, 8] during marine deposition of the Nicosia Formation flanked by the then recently risen margins of the Tróodos Mountains to the south and the Kyrenia Range to the north. The basin fill consists mainly of marl, with some calcarenite, oolite, gravel and sand up to a maximum thickness of $900 \mathrm{~m}$. Its age ranges from late Miocene through Pliocene and probably to early Pleistocene. Clastic support from the rising Tróodos Mountains ranging up to conglomerates intercalates with marine deltaic facies in the basin; the Kephales Member is one example. A low energy equivalent of the Kephales Member is the Lithic Sand Member [2]. The marine Nicosia Formation forms the substratum for the terrestrial Apalós Formation, subject of the present study.

After emergence of the Mesaoria Basin the northward drainage of the Tróodos Mountains today consists of a cut and fill river terrace system which rises up to $70 \mathrm{~m}$ above the current valley floor. The highest part of this terrace system embraces the fluviatile stack of the Apalós Formation with a thickness up to $60 \mathrm{~m}$ [9], recently dated to Pliocene and Pleistocene $[2,10]$.

\section{Sites of investigation}

\subsection{The Vlokkariá Section}

Apalós Formation

The subject of this study, the Apalós Formation, is wellexposed in a man-made cliff some $14 \mathrm{~km}$ southwest of downtown Lefkosía. The cliff cuts the hill Vlokkariá (spelled also Vlokkarká or Flokkarká) at an elevation of 343 m a.s.l. (UTM coordinates: 0522780, 3883194). The cliff itself can be traced for $130 \mathrm{~m}$ and reaches a maximum height of $20 \mathrm{~m}$. The cliff embraces 13 stacked fluviatile units of the Apalós Formation, with each unit generally starting with gravelly channel facies at the base and grading through floodplain deposits with a fossil soil at the top (Figure 2).

Fieldwork began in 1998; in 2002 the outcrop study was 


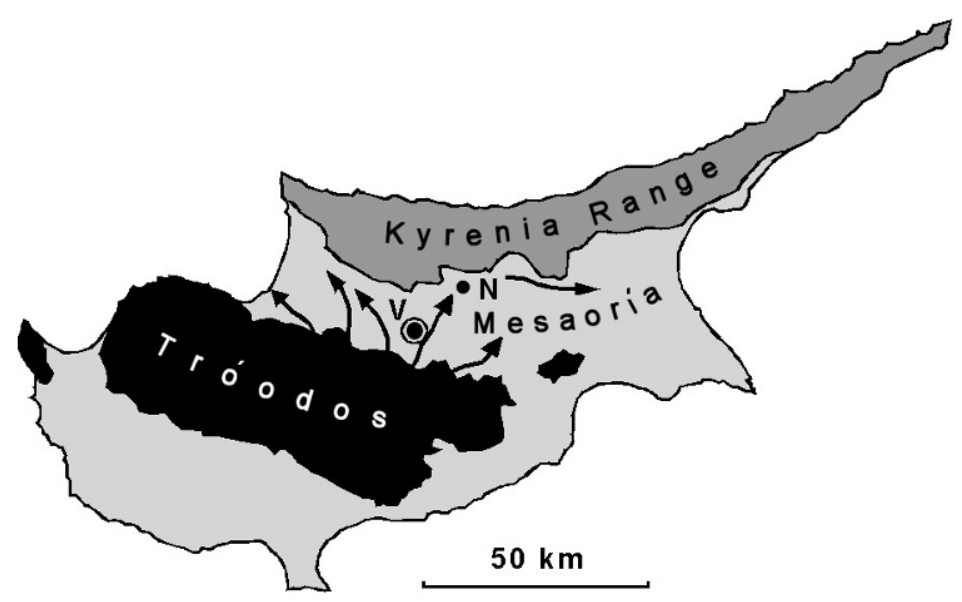

Figure 1. Location of the Vlokkariá Section $(\mathrm{V})$ in Cyprus. $\mathrm{N}=$ Nicosía (Lefkosía). Arrows mark the main drainage directions within the Mesaoría Basin. The Vlokkariá is situated near the water divide between the western and eastern drainage of the Mesaoría Basin.

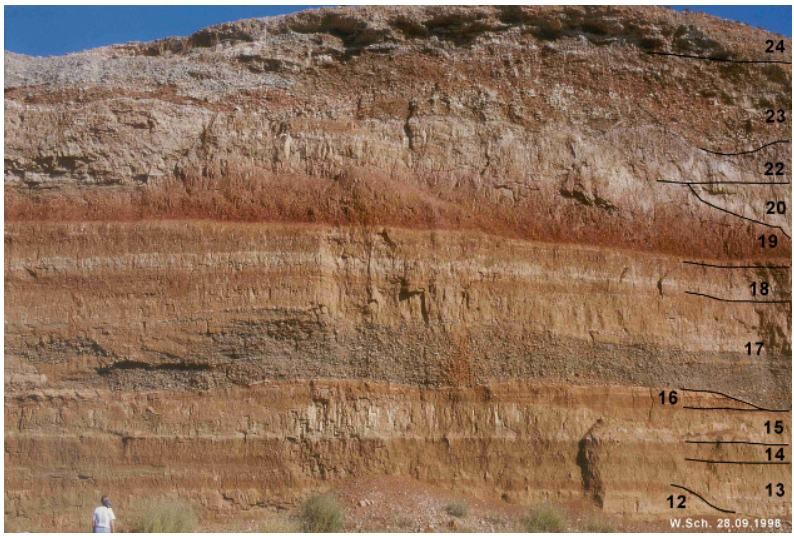

Figure 2. Detail of the Vlokkariá cliff wall. The cliff exhibits 12 of total 24 Fluviatile Series (units) of the Vlokkariá section. The detail (photograph) includes unit 12 to 24 except 21. Photo: W. Schirmer 28.09.1998.

extended downwards by using a rut, thus adding a $4.8 \mathrm{~m}$ vertical section to the cliff with an additional 5 fluviatile units exposed. In 2005 an additional $146.5 \mathrm{~m}$ long and 2.5-3 m deep trench was excavated, extending the section down through the base of the Apalós Formation into the Nicosia Formation (Figure 3). Cliff, rut and trench exposed a total of 24 stacked fluviatile units (Figure 4).

The sediments of the Apalós Formation clearly show cyclic deposition, which is diagnostic for the Fluviatile Series sensu Schirmer [11]. Each cycle starts with an unconformity. Generally, the base over this unconformity is formed by a channel facies (gravel bed) consisting of dark ophiolitic rudites with small amounts of Tertiary carbonate de- posits and with ophiolitic medium grained sand of dark olive colour. The gravel bed is overlain by a graded flood deposit that normally starts with medium to fine sandy loam and passes upwards to silty loam. The flood deposit is topped by a floodplain soil, the intensity of which changes from cambisol through luvisol to nitisol.

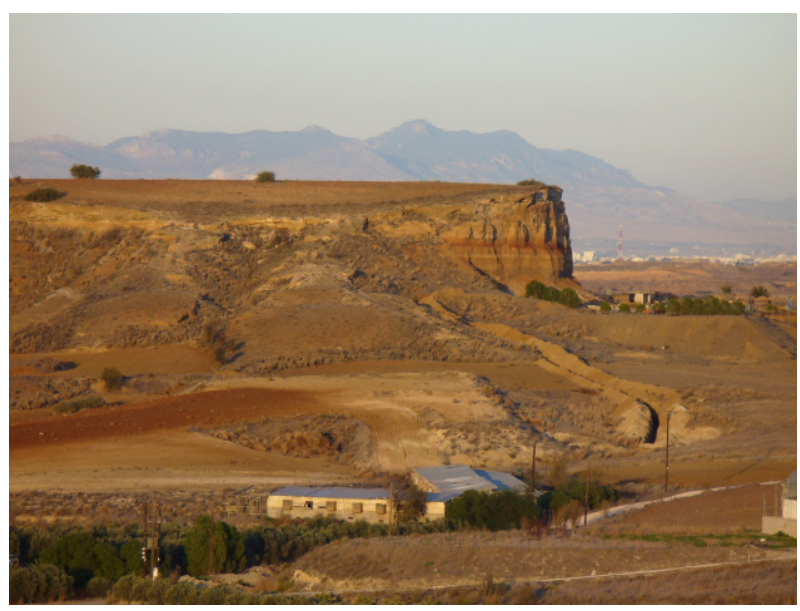

Figure 3. Vlokkariá cliff and the $146.5 \mathrm{~m}$ long artificial trench at its foot. The trench exhibited the basal 12 of total 24 Fluviatile Series of the Vlokkariá section. In the background the outskirts of the town of Nicosia in front of the Kyrenia Range. Photo: W. Schirmer 12.11.2005.

The gravelly channel facies in many cases is locally incised into the upper parts of an older unit; sometimes it has removed the uppermost horizons of the soil topping the underlying unit. In rare cases, as in unit 16, the soil topping the underlying unit was completely removed 
within the Vlokkariá cliff section outcrop. These features underline the existence of unconformities at the base of a unit.

Likewise the channel facies is not present in several of the units, as for example in units 14, 18, 19, 21, 22 and especially in units exposed by the trench, where the lengths of outcropping units were very short. This points to a valley ground with river channels and floodplain. There the river channel is restricted to certain places within the valley ground, however, the floodplain with its fine-grained deposits extends over the complete valley floor.

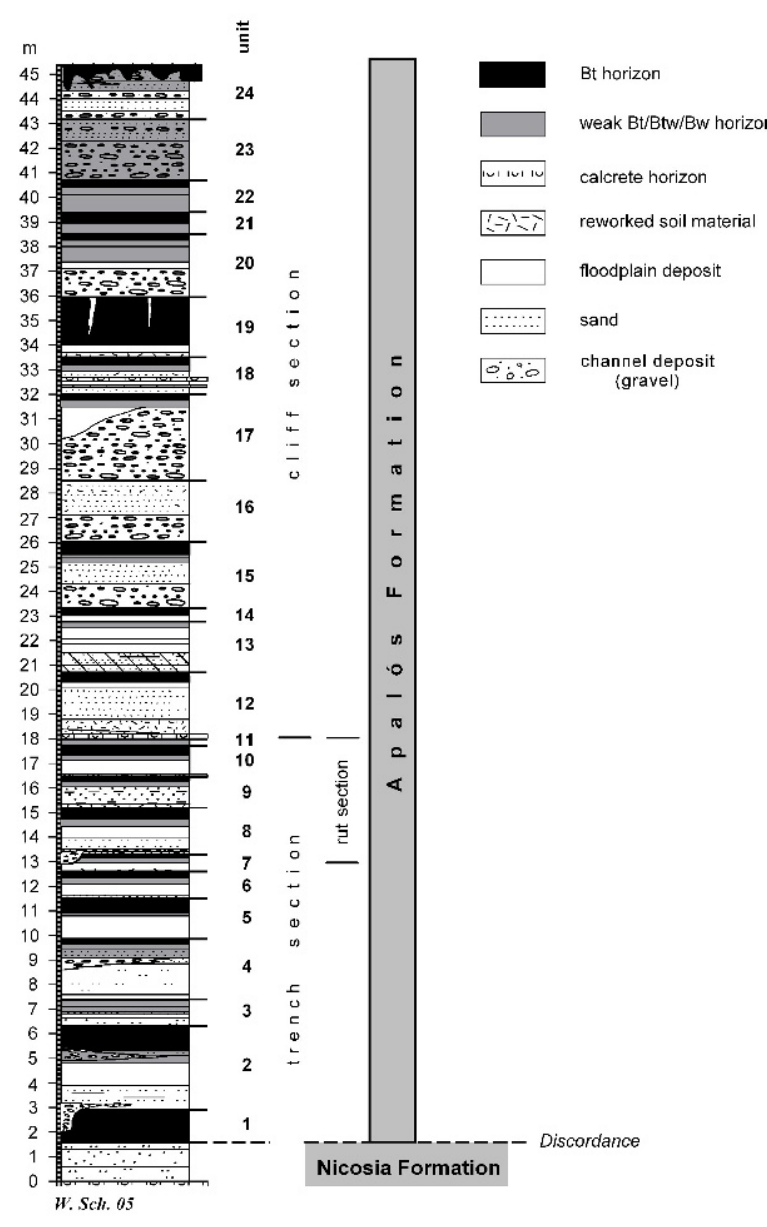

Figure 4. 4 Compiled Vlokkariá section. Lithology of the 24 fluviatile units.

Overall, the fluvial stack of the Apalós Formation shows both cut and fill structure and superposition. The prevailing feature is superposition.

The unconformity at the base of each unit highlights the fact that the whole stack of units may be incomplete. Therefore the number of 24 fluviatile units is a minimum number.
The Apalós Formation is the first recognizable fluvial system on the northern flank of the Tróodos Mountains [8]. Its fluvial stack is morphologically followed by a fluvial staircase that extends down to the recent rivers. Thus, the fluvial system draining the northern Tróodos has formed a discrete unit acting on the land from Early Pleistocene until today - though with a changing fluvial texture.

Lithic Sand Member of the Nicosia Formation

A deposit underlying the Apalós fluvial units (0-1.6 $\mathrm{m}$ in Figure 4) is a green-grey, fine sandy to silty shale full of secondary calcrete. It belongs to the upper part of the Nicosia Formation, the so-called Lithic Sand Member.

\subsection{The Kókkinos Section 1.5 km southwest of the Vlokkariá site}

The search for palaeomagnetic data for the next morphologically younger terrace below the Vlokkariá site yielded a $5 \mathrm{~m}$ thick section in a flat hill with the toponym Kókkinos (UTM grid 0521343-3882176). Below $4 \mathrm{~m}$ of boulder gravel of Tróodos ophiolitic provenance, a $0.7 \mathrm{~m}$ silty yellow-brown flood loam was found, which was in turn topped by a thick cambisol and underlain by gravel. Lower gravel, flood loam and cambisol form one unit; the topping $4 \mathrm{~m}$ thick gravel forms the next sequence.

As it was the only locality investigated within a lower situated fluvial deposit, there remains some uncertainty whether it could represent a younger Pleistocene terrace or a Pliocene Kephales Member ridge [10] of the upper Nicosia Formation. Those gravelly delta ridges rise up in that area to form hummocks.

\section{Investigation methods and their results}

\subsection{Microfauna of the Lithic Sand Member}

Marcelle BouDagher-Fadel characterized the microfauna from the Lithic Sand Member (Nicosia Formation) (Table 1). The samples originate from the lowermost beds within the Vlokkariá trench, meter 0-1,6 (Figure 4) and are mainly barren, except for reworked Middle to Late Eocene and Late Oligocene to Early Miocene planktonic foraminifera. Specimens are rare and mainly broken. Very few broken specimens of benthic foraminifera are reworked into the sediments.

This reworked fauna fits well with the interpretation of the Lithic Sand Member, which represents a delta front facies that started to fill the marine Mesaoría basin with 
ophiolitic material from the uplifting Tróodos flank [10].

\subsection{Grain size distribution of floodplain de- posits within the Vlokkariá Section}

The grain size is useful for three reasons. (1) Grain size characterization enables delimitation of single units precisely by their rhythmicity: coarse at bottom - fine at top. In fluvial rhythms the top is formed by a fossil soil that should be supported by a distinct increase of fines: clay and fine silt. (2) Grain size distribution can also hint at transport regime; another question within these Fluviatile Series is whether the fines originate from flood deposition or wind influx. (3) Finally, for the comparison with the magnetic susceptibility it is essential to know the content and the exact vertical position of fines.

Figure 5 shows analyses from the flood deposits and soils of unit 9 to unit 22. Units 12 to midway through unit 18 were analyzed by the Köhn grain size separation method, 9-11 and mid 18-22 by using a Sedigraph 5100. The Köhn method yielded less fines (clay and fine silt) than the Sedigraph method (cf. [12]).

\section{Results:}

ad 1. In general, toward the top of a unit a distinct fining upward is visible shown by the clay and/or fine silt content corresponding to the decrease of the three sand fractions (fine, medium and coarse sand). Medium silt shows a weak tendency to correlate with the fine fraction, e.g. in units $10,12,13,15,18$ and 21 . Coarse silt remains indifferent.

The fining upward supports the bounds of the units established by their distinct sedimentary sequence: gravel - flood deposit - floodplain soil, the Fluviatile Series [11]. Where soils are fully preserved they are marked by an increase or peak in the clay and fine silt fractions. The fines of the flood deposits below the soils are not influenced by the soil formation.

An exception is shown in unit 19, as indicated by the deeply red soil. Fine and medium silt show an increase upwards as is normal for a fluvial cycle. However, in Figure 2 the deeply red soil (nitisol) presents a picture as to lie upside down with a strikingly sharp base. This points to a flood redeposition of soil material, followed by red soil formation. In addition, within the soil there is a distinct blending-out of the red colour from base to top (Figure 2). The long period of soil formation in unit 19 may have been interrupted by slight and thin silting up by repeated floods, thus thinning the red colour of the soil formation, i. e. synpedological silting up, as it is often observed in fluvisols [13]. Moreover, Figure 5 shows in unit 19 an upward clay retreat. Its maximum conforms to the redeposited soil material. The higher retreat fits with an increase of sand, even coarse sand, toward the top whereas coarse sand is a typical indicator for the base, as seen in units $16,18,19$ and 21 .

An explanation for the occurrence of coarsening upward is given by very small sand dykes, sand filled cracks, cutting from the top of unit 19 downwards and thinning out toward the base of the deeply red soil. These sand dikes produce the coarsening upward of the sand content in the top part of the soil and consequently the diminution of finer shares towards the top.

ad 2. A missing maximum in the values of the coarse silt fraction indicates no considerable eolian input into the top of the rhythms.

ad 3. The relationship of the grain size to the magnetic susceptibility is treated in chapter 4.4 .

\subsection{Magnetostratigraphy}

A total of 445 samples were collected from the fine-grained parts of the Fluviatile Series of the Vlokkariá section at an average vertical distance of about $8 \mathrm{~cm}$ between samples. Natural remanent magnetization (NRM) analysis of the samples (partly in [14]) including demagnetisation in alternating fields revealed the presence of a very well defined direction of characteristic remanent magnetization (ChRM) in most of the samples (Figure 6) pointing either to the north and down (Dec: $358.3^{\circ} \mathrm{E}$, Inc: $+45.5^{\circ}$, $\alpha$ 95: $2.9^{\circ}, \mathrm{k}: 37.6, \mathrm{~N}: 65$ ) or to the south and up (Dec: $176.3^{\circ} \mathrm{E}$, Inc: $-49.6^{\circ}, \alpha$ 95: $\left.1.9^{\circ}, \mathrm{k}: 33.3, \mathrm{~N}: 175\right)$. A positive reversal test, classified " $A$ " according to McFadden et al. [15], supports the primary character of the characteristic magnetization. The magnetostratigraphic correlation of the ChRM polarity pattern observed at Vlokkariá (Figure 7) with a geomagnetic polarity timescale modified from Berggren et al. [16] is shown in Figure 8. The major portion of the samples is reversely magnetized and interpreted to represent the main part of the Matuyama polarity zone. The long period of reverse magnetism bracketed by the Pliocene Nicosia Formation and the Middle Pleistocene terrace staircase can only represent the Lower Pleistocene Matuyama chron. The longest normal events therein are the Olduvai and the Jaramillo subchrons. Both normal events of the Vlokkariá section cover longer fluvial periods; thus, it is assumed that they represent these two zones of normal polarity, the Olduvai (1.95-1.77 Ma) and Jaramillo (1.07-0.99 Ma) subchrons, respectively.

Samples taken from the geomorphologically lowerposition terrace at Kókkinos show exclusively normal directions, which might be correlated with the early Brunhes chron ( $\leqslant 0.78 \mathrm{Ma}$ ) unless they were magnetized during the Gauss chron (cf. chapt. 3.2). Pre-Apalós sediments at the bottom of the Vlokkariá section show transitional polar- 
Table 1. Foraminiferal content of the Lithic Sand Member.

\begin{tabular}{|c|c|}
\hline Meter & Foraminiferal content \\
\hline $0-0.60$ & barren \\
\hline \multirow[t]{8}{*}{$0.60-0.84$} & Rare Late Oligocene-earliest Miocene reworked foraminifera: \\
\hline & Catapsydrax dissimilis (Cushman and Bermudez, 1937) \\
\hline & Globigerina woodi Jenkins, 1960 \\
\hline & Globorotalia kugleri Bolli, 1957 \\
\hline & Globigerina brazieri Jenkins, 1966 \\
\hline & Globigerina ciperoensis Bolli, 1957 \\
\hline & Globigerina preabulloides Blow, 1959 \\
\hline & Rare benthic foraminifera: Cibicidoides spp., Baggina spp., Uvigerina spp. \\
\hline \multirow[t]{5}{*}{ 0.84-1.06 } & Reworked Early Miocene: \\
\hline & Globigerina ciperoensis Bolli, 1957 \\
\hline & Globigerina preabulloides Blow, 1959 \\
\hline & Globigerina brazieri Jenkins, 1966 \\
\hline & Globigerina spp. \\
\hline \multirow[t]{10}{*}{$1.06-1.30$} & Planktonic foraminifera: \\
\hline & Miocene to Holocene: Orbulina bilobata (d'Orbigny, 1846) \\
\hline & Reworked Middle Eocene: \\
\hline & Morozovella subbotinae (Morozova), 1929 \\
\hline & Reworked Middle to Late Eocene: \\
\hline & Globigerina eocaena Guembel, 1868 \\
\hline & Reworked Early Miocene: \\
\hline & Globigerina preabulloides Blow, 1959 \\
\hline & Globigerina brazieri Jenkins, 1966 \\
\hline & Globigerina spp. \\
\hline \multirow[t]{11}{*}{$1.30-1.60$} & Middle to Late Eocene reworking: \\
\hline & Globigerina eocaena Guembel, 1868 \\
\hline & Acarinina spp. \\
\hline & Reworked Early Miocene: \\
\hline & Globigerina spp., \\
\hline & Globigerina angustiumbilicata Bolli, 1957 \\
\hline & Globigerina ciperoensis Bolli, 1957 \\
\hline & Early Miocene: \\
\hline & Globigerina connecta Jenkins, 1964 \\
\hline & Globigerina brazieri Jenkins, 1966 \\
\hline & Benthic foraminifera: Bolivina spp., Nonion spp. \\
\hline
\end{tabular}

ity behaviour and therefore might reflect the beginning of the Réunion event (2.15 Ma) or the beginning of another earlier normal event.

\subsection{Magnetic susceptibility}

Prior to demagnetization, the magnetic low field susceptibility of each sample was measured using a KLY-4 Kappabridge (AGICO). Results have been plotted and compared with the lithological sequence in Figure 9 with the aim of gaining information about the Plio-Pleistocene palaeoclimate of the eastern Mediterranean. Heller and
Evans [17] among others have demonstrated that the susceptibility of the wind-blown Chinese loess-palaeosol sequence is linked to the palaeoclimatic conditions during sedimentation. Susceptibility increases under warmhumid climate conditions due to neo-formation of ferrimagnetic minerals when soils are developing whereas the loess deposited during cold-arid conditions carries usually a much smaller susceptibility signal originating from the desert dust.

In the Vlokkariá section, the susceptibility (Figure 9) increases in some cases toward soil formations e.g. in units 1 and 5. In other cases soils are completely neglected 


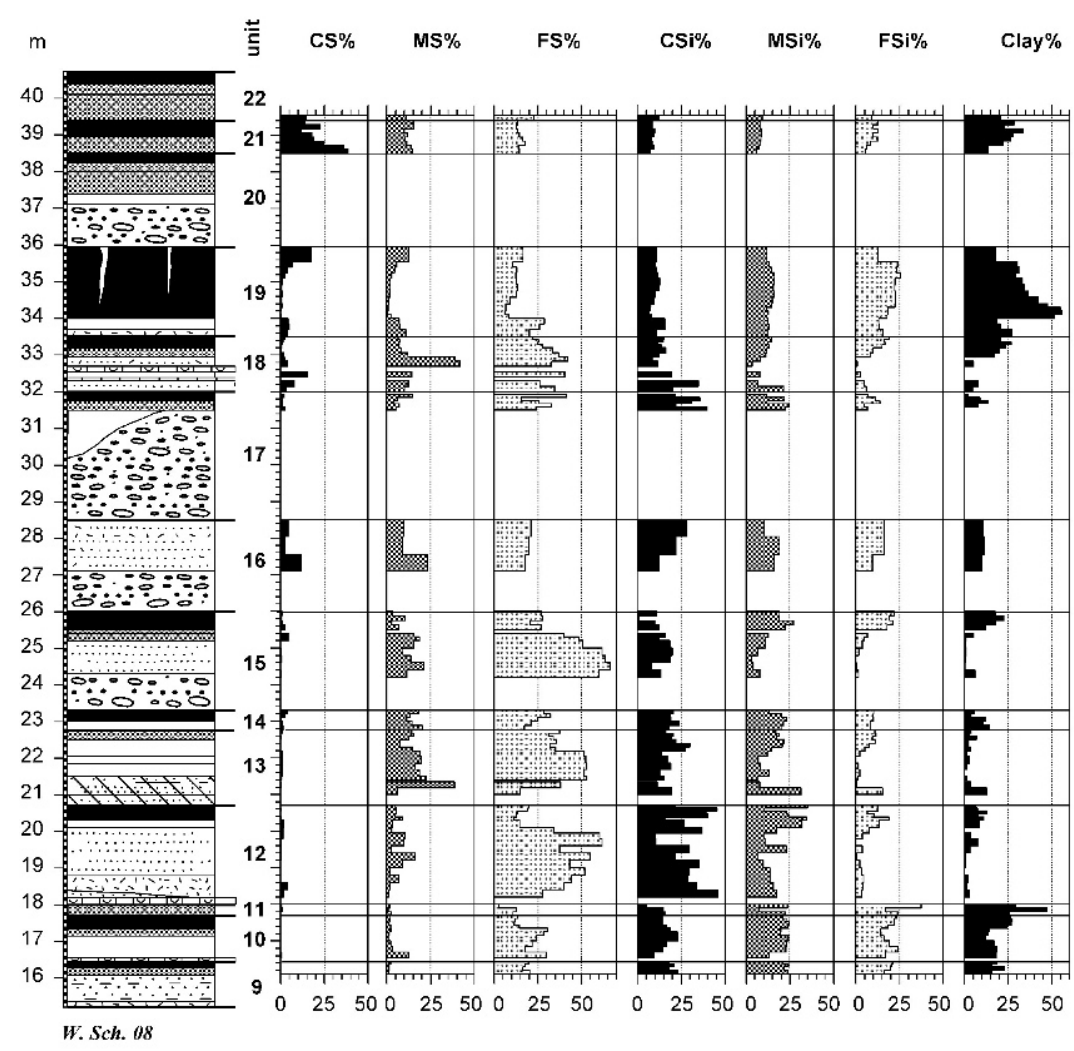

Figure 5. Vlokkariá section. Grain size distribution of some floodplain deposits.

by the susceptibility curve. The strongest soil within the Vlokkariá section, the deeply red soil in unit 19, exhibits low values. Likewise clay peaks (Figure 5) do not correspond with enhanced susceptibility.

However, ophiolitic sand and gravel essentially show peaks of the susceptibility curve as seen in units 4 and 9. The highest single values occur at the bases of units 8 and 20 in sandy-gravelly layers that occur within flood loam strata close to the underlying gravel.

Consequently, the susceptibility of the fluvial deposits spread from the Tróodos Mountains turns out to be controlled by their ophiolitic shares. This explains that peaks within the fluviatile Vlokkariá sections occur in sandygravelly deposits. Thus, the ophiolitic component veils a possible climatic signal given by the fossil floodplain soils.

\section{Conclusions}

1. The $45.5 \mathrm{~m}$ thick Vlokkariá section is composed of a $27 \mathrm{~m}$ cliff section on top and $18.5 \mathrm{~m}$ trench section at its base. It exposes the Apalós Formation, consisting of 24 fluvial units, the first terrestrial deposits after a tapering marine Pliocene history of the area. Stratigraphically the Apalós Formation turns out to extend over a great deal of the Matuyama chron comprising the Jaramillo subchron, identified in the upper part of the cliff section, and the Olduvai subchron lying within the trench section. The Olduvai subchron starts at $1.95 \mathrm{Ma}$ (Figure 8). Prior to it, $4.5 \mathrm{~m}$ Apalós Formation were deposited (Figure 7). As the Réunion event ending by 2.14 Ma has not been found in this basal part of the Apalós Formation, the base of this formation is considered to lie at around $2 \mathrm{Ma}$ BP.

The occurrence of the Jaramillo event in the upper part of the Apalós Formation points to the fact that the Matuyama/Brunhes chron boundary should follow soon after the fluvial dissection of the Apalós Formation. For this reason the Kókkinos site has been investigated palaeomagnetically as well (chapt. 3.2). Its sedimentology and normal polarity palaeomagnetism are likely to represent Brunhes age. However there is still doubt whether the normal polarity ChRM originates from a Gauss age Kephales Member of the Nicosia Formation. The top of the Apalós Formation in the Vlokkariá section is considered to lie around $0.85 \mathrm{Ma}$. Thus, the Apalós Formation at Vlokkariá comprises the time span from about $2 \mathrm{Ma}$ 


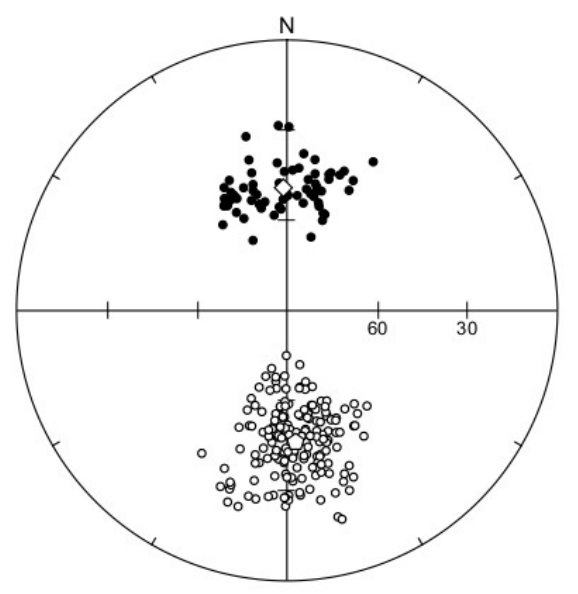

Figure 6. Vlokkariá section. Stereographic projection of characteristic NRM directions (intermediate directions and poor quality data have been excluded for determination of mean directions and reversal test) obtained from 199 palaeomagnetic samples.

to about $0.85 \mathrm{Ma}$, a duration of around 1.15 Ma. Consequently, deposition of the Apalós Formation occurred entirely within the Early Pleistocene without overlapping the lowermost and uppermost parts of the Early Pleistocene.

2. Below the fluvial Apalós Formation, $1.6 \mathrm{~m}$ of fine sandy marl exposed in the trench produced few foraminifera. They are mainly reworked ranging in age from Eocene to Early Miocene. This marl belongs to the Lithic Sand Member within the upper part of the marine Nicosia Formation. This Lithic Sand Member is thought to be a Tróodos sand gift to the shallow sea environment of the upper Nicosia Formation [10]. In the Vlokkariá section, its palaeomagnetism is intermediate pointing from reverse at base to normal at top. If it represents the base of the Réunion event (2.15 Ma), the Lithic Sand Member is at least in its upper part of Early Pleistocene age. However, there is also a possibility that the palaeomagnetic signature represents the upper boundary of a reverse event within the Gauss chron. In this case, the Nicosia Formation would be Pliocene as a whole.

3. The hiatus between the Nicosia and the Apalós Formations is bracketed at its top by the base of the Apalós Formation at about $2 \mathrm{Ma}$ and at its base by any level within the Lithic Sand Member of the Nicosia Formation. The youngest known deposits underlying the Apalós Formation are rocks of the marl member of the Nicosia Formation of the foraminiferal zone 21 [2]. This zone is dated between 3.0 and 2.0 Ma (cf. [18]). Thus, the hiatus may

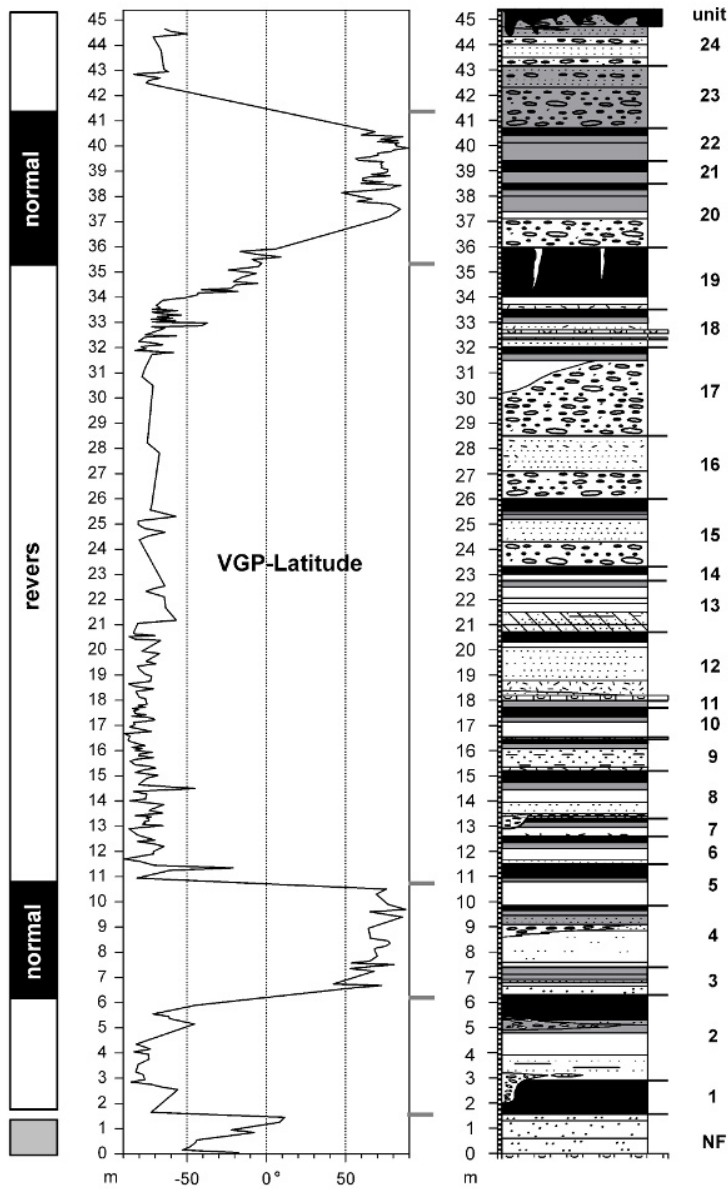

Figure 7. Vlokkariá section. Palaeomagnetic polarity pattern (left), VGP latitudes (middle) and lithology (right). Units 1-24 represent the Apalós Formation, NF the Nicosia Formation. Note some VGP data gaps around the upper normal polarity zone caused by low stability samples.

encompass at minimum very little time and at maximum $1 \mathrm{Ma}$.

4. Concerning vertical movements of the Tróodos Mountains and their northern slopes, the first important signal is the increase in clastic sedimentation within the Nicosia Formation toward the northern Tróodos rim. This increase is present in the Kephales Member and the Lithic Sand Member which show reworking of deposits and microfossils of the circum Tróodos sedimentary succession [2], thus indicating Pliocene uplift of the Tróodos Mountains. Further uplift of the whole area is indicated by the change from marine to terrestrial sedimentation toward the Pliocene/Pleistocene boundary. Although Schirmer [19] could reject the arguments for a postulated Late Pliocene rapid Tróodos uplift documented in the Choirokoitía area (southeastern Tróodos side), uplift was nevertheless present during that time. 


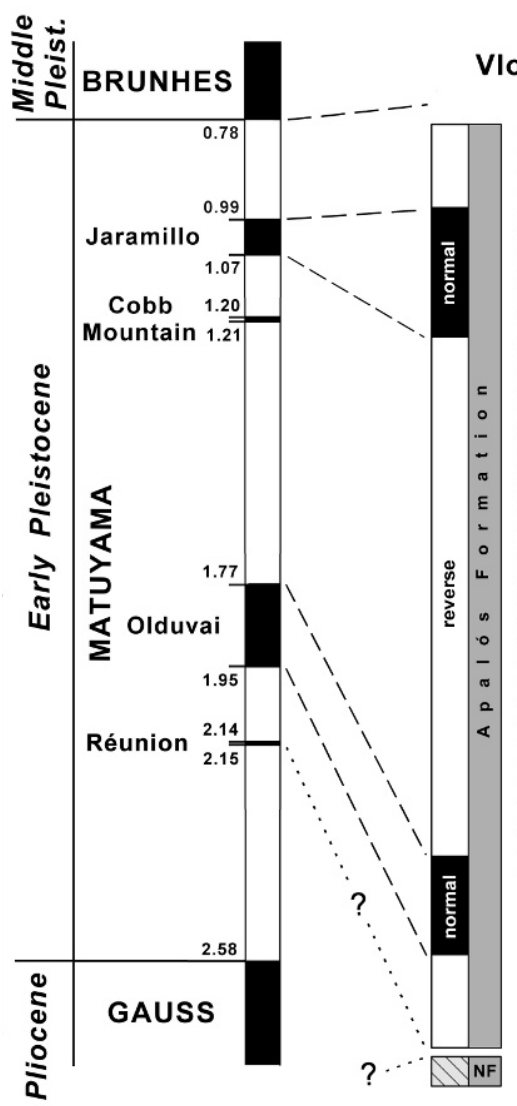

\section{Vlokkariá section}

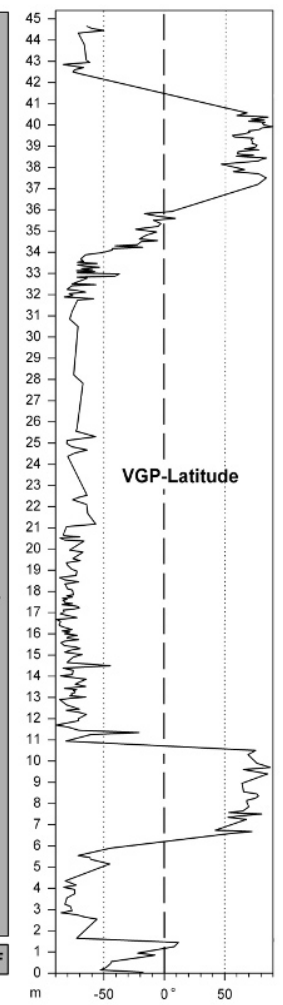

Figure 8. Magnetostratigraphic correlation of the polarity pattern observed at the Vlokkariá section (right) with a geomagnetic polarity timescale (modified from Berggren et al. [12]) (left). Black (white) bars show normal (reverse) polarities. Hachured bar represents zone of uncertainty below a gap between Apalós Formation above and Nicosia Formation (NF) below. Numbers in the stratigraphical scale are million years.
The 24 cycles of the Apalós Fluviatile Series in the Vlokkariá area lie at similar elevation with a tendency toward superposition. As they form the first terrestrial deposits at the northern rim of the Tróodos Mountains, a very flat and deeply lying river environment is considered. This long lasting fluvial sediment stacking either may have compensated an oversteepened relief prior to the Apalós Formation, or more likely may have resulted from a very gentle and steady uplifting of the Tróodos hinterland. By contrast, enhanced Tróodos uplift started the dissection of the stacked river plain at the end of the Early Pleistocene. This dissection continued through the Middle Pleistocene, leaving some terrace accumulations in between. Thus, the Tróodos uplift shows a pronounced pulsing history.
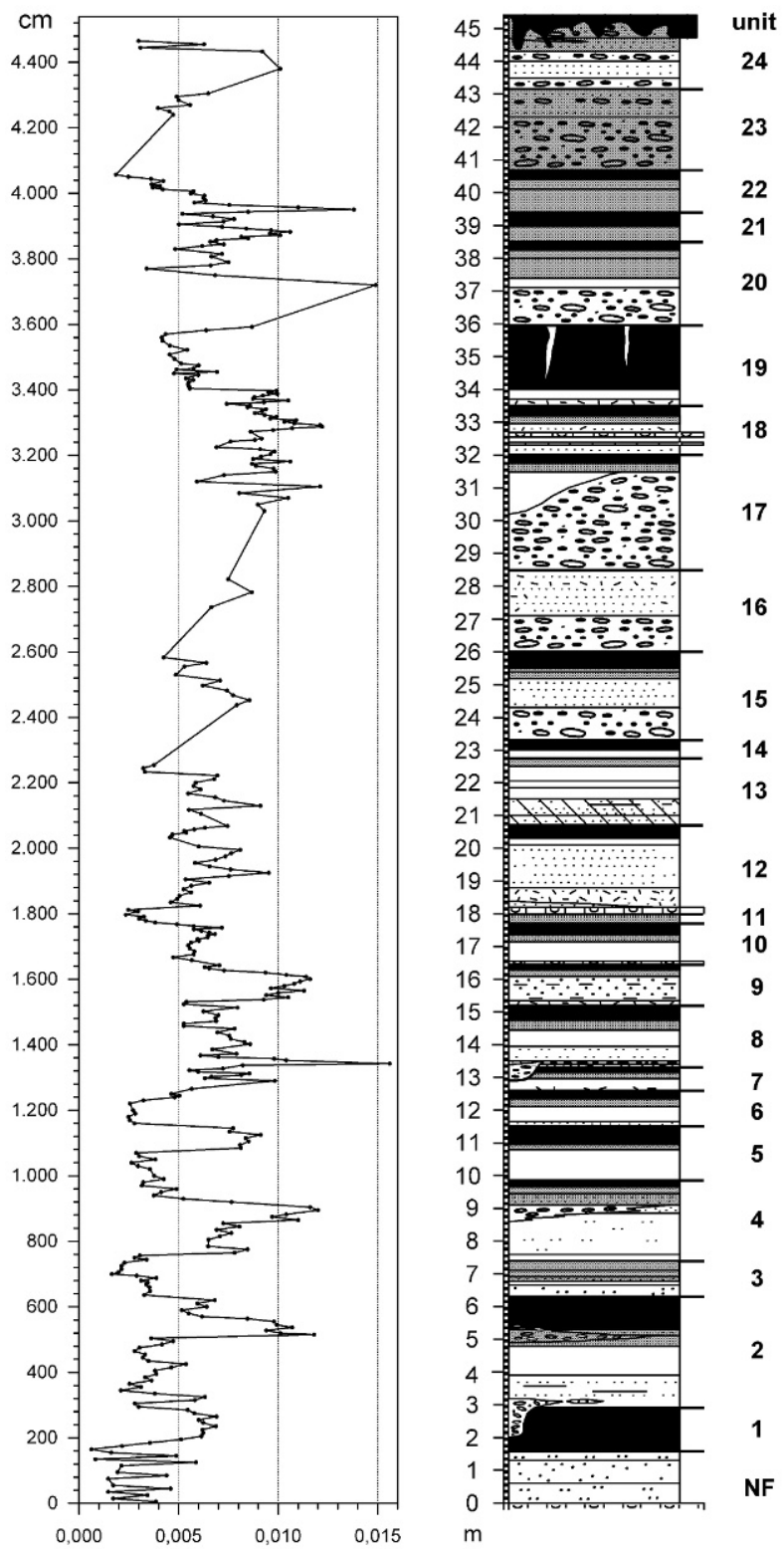

Figure 9. Vlokkariá section. Susceptibility (left) in comparison to geological strata (right). Unit 1-24 represent the Apalós Formation, NF the Nicosia Formation.

\section{Acknowledgements}

Thanks go to Dr. Lars Cofflet, Dr. Alexander Ikinger and Michael Wack for their helpful assistance during fieldwork. We are grateful to Arie W. Janssen, Gozo/Malta, for checking the samples of the Lithic Sand Member with regard to pteropods. We thank Prof. Alan Lord, London, and Constantinos Lordos, Pyrgá/Cyprus, for their logistic help. Thanks are also due to two unknown reviewers. The 
German Research Foundation supported travelling, trench excavation, forklift costs and a student worker.

\section{References}

[1] Harrison R. W., Newell W. L., Batihanli H., Panayides I., McGeehin J. P., Mahan S. A., Özhür A., Tsiolakis E. et al., Tectonic framework and Late Cenozoic tectonic history of the northern part of Cyprus: implications for earthquake hazards and regional tectonics, J. Asian Earth Sc., 2004, 23, 191-210

[2] Harrison R., Newell W., Panayides I., Stone B., Tsiolakis E., Necdet M., Batihanli H., Özhür A., et al, Bedrock geologic map of the greater Lefkosia area, Cyprus. US Geol. Survey, Sci. Investigation Map, 2008, 3046, scale 1:25000

[3] Gass I. G., Masson-Smith D., The geology and gravity of the Troodos Massif, Cyprus. Philosophical Transactions Royal Society of London, 1963, A 255, 417-467

[4] Kempler D., Ben-Avraham Z., The tectonic evolution of the Cyprean Arc, Annales Tectonicae, 1987, 1, 5871

[5] Robertson A. H. F., Tectonic evolution of Cyprus. In: Malpas J., Moores E. M., Panayiotou A., Xenophontos C. (Eds.), Ophiolites. Oceanic crustal analogues. Proceedings of the Symposium „Troodos 1987". Geological Survey Department, Nicosia, 1990, 235-250

[6] Robertson A. H. F., Tertiary uplift history of the Troodos massif, Cyprus, Geol. Soc. America Bull., 1977, 88, 1763-1772

[7] Gass I. G., The Troodos massif: Its role in the unravelling of the ophiolite problem and its significance in the understanding of constructive plate margin processes. In: Panayiotou A. (Ed.): Ophiolites. Proceedings Intern. Ophiolite Symp. Cyprus 1979, Geol. Surv. Dep., Nicosia, 1980, 23-35,

[8] McCallum J. E., Robertson A.H.F., Sedimentology of two fan-delta systems in the Pliocene of the Mesaoría Basin, Cyprus, Sediment. Geol., 1995, 98, 215-244

[9] Ducloz C., Revision of the Pliocene and Quaternary stratigraphy of the Central Mesaoría. Annual Report Geol. Survey Dept. Cyprus 1964, Nicosia 1965

[10] Newell W., Stone B., Harrison R., Tsiolakis E., Panayides I., Batihanli H., Necdet M., Berksoy et. al, Surficial geology of the Nicosia area. In: DeCoster M., Zomeni Z., Panyides I., Petrides G., Berksoy O. (Eds.), Seismic hazard and risk assessment of the greater Nicosia area. CD, Geological Survey Department, Nicosia, 2004, 40-59

[11] Schirmer W., Die Talentwicklung an Main und Regnitz seit dem Hochwürm. Geol. Jahrbuch A, 1983, 71,
11-43, (in German)

[12] Duck R.W., Application of the QDa-Md method of environmental discrimination to particle size analyses of fine sediments by pipette and sedigraph methods: a comparative study, Earth Surf. Proc. Land., 1983, 19, 525-529

[13] Schirmer W., Zur Nomenklatur der Auenböden mitteleuropäischer Flussauen. Mitteilungen der deutschen bodenkundlichen Gesellschaft, 1991, 66, 839-842 (in German)

[14] Weber J., Paläo- und gesteinsmagnetische Untersuchungen an fluviatilen Sedimenten der Lokalität Flokkarka, Zypern. Diplomarbeit Department für Geo- und Umweltwissenschaften der LMU München, 1991, (in German)

[15] McFadden P.L., McElhinny M.W., Classification of the reversal test in palaeomagnetism. Geophys. J. Int., 1990, 103, 725-729

[16] Berggren W.A., Hilgen F.J., Langereis C.G., Kent D.V., Obradovich J.D., Raffi I., Raymo M.E., Shackleton N.J., Late Neogene chronology; new perspectives in highresolution stratigraphy. Geol. Soc. Am. Bull., 1995, 107, 1272-1287

[17] Heller F., Evans M.E., Magnetoklimatologie, Mineralmagnetismus und Eiszeiten. Naturwissenschaften, 1996, 83, 97-102 (in German)

[18] Lord A.R., Panayides I., Urquhart E., Xenophontos, C., A chronobiostratigraphical framework for the Late Cretaceous-Recent circum-Troodos sedimentary sequence, Cyprus. In: Panayides J., Xenophontos C., Malpas J. (Eds.), Proceedings of the Third International Conference on the Geology of the Eastern Mediterranean. Geological Survey Department, Nicosia, 2000, 289-297

[19] Schirmer W., Neogene submarine relief and Troodos uplift in southeastern Cyprus. In: Panayides J., Xenophontos C., Malpas J. (Eds.), Proceedings of the Third International Conference on the Geology of the Eastern Mediterranean. Geological Survey Department, Nicosia, 2000, 125-134 